\title{
Natural Antioxidant from Yerba Maté (Ilex paraguariensis St. Hil.) Prevents Hamburger Peroxidation
}

\author{
Erica Lemos Ferreira, Geni Rodrigues Sampaio, Elizabeth Aparecida Ferraz da Silva \\ Torres and Deborah Helena Markowicz Bastos \\ Departamento de Nutrição; Faculdade de Saúde Pública; Universidade de São Paulo; Av. Dr. Arnaldo, 715; \\ 01246-904; São Paulo - SP - Brasil
}

\begin{abstract}
The aim of this study was to evaluate whether yerba maté alcoholic extracts at very low concentrations (0.01 and $0.1 \%$ ), prevent/retard lipid peroxidation in beef hamburgers without impairing sensory acceptability. For this TBARs and hexanal levels, fatty acid profile and cholesterol oxides were evaluated as oxidation parameters in beef hamburgers during 90 days' storage. The addition of $0.01 \%$ yerba maté ethanolic extracts proved inefficient in restraining the lipid peroxidation while the addition of $0.1 \%$ resulted in efficient antioxidant activity. Sensory evaluation of hamburger containing $0.1 \%$ yerba maté ethanolic extracts showed good acceptability. Yerba maté ethanolic extracts could entirely or partially replace the phenolic synthetic antioxidants in beef hamburgers only when used at above legally allowed concentrations for antioxidant additives $(0.01 \%)$.
\end{abstract}

Key words: Yerba maté, lipid oxidation, natural antioxidants, hamburger

\section{INTRODUCTION}

Food containing high concentrations of prooxidant substances (such as transition metal, heme protein) and polyunsaturated fatty acids are easily attached by free radicals and undergo oxidation. This may cause rancidity, decreasing both acceptability and nutritional value of the food. Lipid peroxidation causes degradation of polyunsaturated fatty acids and the generation of residual products, such as malondialdehyde and lipid-derived volatiles, which may lead to sensory and nutritional deterioration of meat (Gray et al., 1996; Gray and Pearson, 1987). To prevent and retard lipid oxidation, addition of synthetic antioxidants, such as butylated hydroxyanisole
(BHA) and buthylated hydroxytholuene (BHT), are often necessary to increase the shelf life of food products. The replacement of these synthetic antioxidants by plant extracts, the so-called natural antioxidants, is a public health concern, since extensive use of synthetic antioxidants and prolonged ingestion may be associated with the development of cancer (Sasse et al., 2009; Pokorný, 2007; Dwivedi et al., 2006; PérezMateos et al., 2006; Schilderman et al., 1995).

Antioxidant properties of different plants extracts have been analyzed for this purpose, includingsage (Salvia officinalis), rosemary (Rosmarinus officianalis), oregano (Origanum onites), and many others (Hernández-Hernández et al., 2009; Estévez et al., 2007; Ahn et al., 2002).

\footnotetext{
*Author for correspondence: dmbastos@usp.br
} 
Dried leaves of yerba maté (Ilex paraguariensis), a native South American plant, are used to prepare an aqueous infusion called "chimarrão", which is rich in phenolic acids (Bastos et al., 2005; Bastos et al., 2006; Mazzafera, 1997) and has shown in vitro and in vivo antioxidant activity, besides other pharmacological properties. Roasted leaves from yerba maté, which are brewed to produce maté-tea, also contain high levels of polyphenols and demonstrate in vitro and in vivo antioxidant activity (Bastos et al., 2007). The addition of green yerba maté ethanolic extract to pork and back fat from pig salamis $(5 \mathrm{~mL} / \mathrm{Kg})$ lowered TBARs values and volatile compounds derived from lipids (Campos et al., 2007). Racanicci et al. (2008) reported that the addition of an aqueous yerba maté extract $(0.05 \%$ and $0.10 \%)$ to chicken meat balls decreased the lipid peroxidation, measured by TBARs assay and depletion of vitamin $\mathrm{E}$. Despite describing good antioxidant activity in meat products, none of these previous studies evaluated if the addition of green yerba maté extract had an impact on the product acceptance by the consumer, a fundamental parameter for the feasibility of replacing a synthetic antioxidant by a natural one.

This study sought to evaluate whether the addition of ethanolic extract from green yerba and roasted yerba maté (maté tea) could retard lipid peroxidation in bovine meat hamburger.

To our knowledge, there are no previous reports on the antioxidant activity of yerba maté (Ilex paraguariensis St. Hil.) ethanolic extracts in bovine meat systems or its effect on sensory properties.

\section{MATERIAL AND METHODS}

\section{Extraction procedure and extract characterization}

Dried green maté leaves and roasted maté-tea harvested and produced in Paraná, Brazil were obtained from Leão $\mathrm{Jr}^{\circledR}$ (Paraná, Brazil). Ethanolic extracts were prepared according to Bastos et al. (2009). Total phenolics content of the ethanol extract was determined in accordance with the method of Singleton and Rossi (1965), using chlorogenic acid as the standard. Total phenolic compounds in green yerba maté (GYM) and roasted yerba maté (RYM) ethanolic extracts were $28 \%$ and $22 \%(\mathrm{w} / \mathrm{w})$, respectively.

\section{Hamburger preparation and storage}

Hamburgers weighing $60 \mathrm{~g}$ were prepared as follows: beef meat (42g) was chopped, minced, weighed, mixed with of food grade salt $(1.2 \mathrm{~g})$, animal fat $(12.9 \mathrm{~g})$, potable water $(1.8 \mathrm{~g})$, onion $(1.8 \mathrm{~g})$, garlic $(0.18 \mathrm{~g})$ and white pepper $(0.12 \mathrm{~g})$. Hamburgers were divided in six groups: (C) control group (no antioxidant addition); (BHT) butylated hydroxytoluene group (to which 100 ppm of BHT was added); (GYM 0.01) green maté extract $0.01 \%$ (to which $100 \mathrm{ppm}$ of etanolic green yerba maté extract was added); (GYM 0.1) green maté extract 0.1\%; (RYM 0.01) roasted maté extract $0.01 \%$ and (RYM 0.1 ) roasted yerba maté $0.1 \%$. Hamburgers were prepared with exactly the same ingredients, following the good manufacture practices (GMP), wrapped in PVC film and kept at $-18^{\circ} \mathrm{C}$ until analysis. Analysis were performed in three replicates on days $1,30,60$, and 90 during cold storage for secondary lipid oxidation products (as TBARS), hexanal, cholesterol oxides, fatty acid profile and sensory acceptance.

\section{Proximate and fatty acid analysis}

Moisture, total protein and ash were determined according to the official methods (AOAC, 1995). Lipids were extracted as described by Folch et al. (1957). Fatty acid methyl esters (FAMEs) were prepared by saponification and methylation in the presence of $\mathrm{BF}_{3}$ in methanol (Metcalfe et al., 1966). Fatty acid analysis was performed in a Shimadzu GC 2010 gas chromatograph equipped with a FID detector, using the following conditions: split injection (1:80 injection volume $1 \mu \mathrm{L}$ ); capillary column SP 2560 (Supelco) $(100 \mathrm{~m}$; $0.25 \mu \mathrm{m}$ and $0.2 \mu \mathrm{m}$ film); injection port and of detector temperature were $250^{\circ} \mathrm{C}$ and $260^{\circ} \mathrm{C}$, respectively. Initial oven temperature was $140^{\circ} \mathrm{C}$ and increased to $240^{\circ} \mathrm{C}\left(4^{\circ} \mathrm{C} / \mathrm{min}\right)$, which was kept for 15 minutes; carrier gas was hydrogen at $1.5 \mathrm{~mL} / \mathrm{min}$ flow rate. The identification of the fatty acids was done by comparing of their retention times with pure standards (FAME 37, code 47885, Sigma Chemical Co). Fatty acid composition was expressed as percentage of total FAMEs.

\section{Thiobarbituric acid-reactive substances (TBARS)}

TBARs assay was performed as described by Vyncke (1975) and modified by Sorensen and Jorgensen (1996). TEP (1,1,3,3 
tetraethoxypropane) was used as standard at six different concentration $(0.5$ to $24 \mu \mathrm{mol} / \mathrm{L})$ Absorbance was read at $532 \mathrm{~nm}$ and $600 \mathrm{~nm}$ in a Shimadzu UV1650PC spectrophotometer. Values are expressed as $\mathrm{mg}$ of thiobarbituric acid reactive substances per $1000 \mathrm{~g}$ meat (TBARs value).

\section{Cholesterol and cholesterol oxides (7ß-OH, $7 \alpha-$} $\mathrm{OH}, 7-\mathrm{Keto}$ and 25-OH)

Cholesterol and cholesterol oxides were extracted as described by Csallany and Ayaz (1976) adapted from Folch et al. (1957). Forty microliters of each extract (100mg lipids) were evaporated in vacuum rotary evaporator $\left(\mathrm{Büchi}^{\circledR}\right)$ and freed of solvent by using a nitrogen flush, dissolved in $3 \mathrm{~mL}$ of mobile phase and injected into HPLC (Thermo Separation Products ${ }^{\circledR}$ - TSP) equipped with pump (SpectraSystem and Spectra Series Gradient Pumps), degasser (SCM Vacuum Membrane Degasser), UV/VIS detector (SpectraSystem UV/VIS Detectors), automatic injector (SpectraSystem and Spectra Series Autosamplers) , following the method described of Vicente and Torres (2007). A CN column $(25 \mathrm{~cm} \times 0.4 \mathrm{~cm}$ and spherical particles of $5 \mu \mathrm{m}$ ) was used, and the mobile phase was a mixture $(97: 3, \mathrm{v} / \mathrm{v})$ of hexaneisopropanol with flow rate $1.0 \mathrm{ml} / \mathrm{min}$. Injection volume was $20 \mu \mathrm{L}$. Wavelength used for cholesterol and cholesterol oxides determination were either $206 \mathrm{~nm}(25-\mathrm{OH}, 7 \alpha-\mathrm{OH}$ and $7 \beta-\mathrm{OH})$ or $233 \mathrm{~nm}$ (7-Keto). The identification of cholesterol and cholesterol oxides was done by comparing their retention times with those of pure standards (Steraloids Inc. - USA).

\section{Hexanal determination}

Hexanal isolation from hamburger was performed using solid-phase microextraction (SPME) according to Brunton et al. (2000). Briefly, 5g of hamburger was homogenized with $25 \mathrm{~mL}$ distilled water. Aliquots $(5 \mathrm{~mL})$ of the homogenates were dispensed into $20 \mathrm{~mL}$ vial fitted with polytetraflouroethylene (PTFE) lined silicone septa, which were placed in a water bath set at $40^{\circ} \mathrm{C}$ and allowed to equilibrate for 5 minutes. The SPME fiber was introduced into the vial headspace and held for 20 minutes to absorption. A $65 \mu \mathrm{m}$ polydimethylsiloxane/divinylbenzene

(PDMS/ DVB) (Supelco ${ }^{\circledR}$ ) fiber, preconditioned prior to analysis, as described by the manufacturer $\left(250^{\circ} \mathrm{C} / 5 \mathrm{~min}\right)$, was used. Analyses were performed on a gas chromatograph (Cromacon Ciola ${ }^{\circledR}$, Simple Chrom II) equipped with a flame ionizing detector (FID) using a $5 \%$ diphenyl capillary column $(30 \mathrm{~m} \times 0.32 \mathrm{~mm}$ id, $1 \mu \mathrm{m}$ of the film thickness). The carrier gas was hydrogen with flow rate $1.0 \mathrm{~mL} / \mathrm{min}$. The injection port was in the splitless mode and the desorbing time was 3 minutes at $200^{\circ} \mathrm{C}$. The initial oven temperature was $40^{\circ} \mathrm{C}$ (kept for 5 minutes) and increased to $200^{\circ} \mathrm{C}$ at $7^{\circ} \mathrm{C} / \mathrm{min}$. Detector temperature was $220^{\circ} \mathrm{C}$. Hexanal identification was performed by comparing the retention times with hexanal standard (Sigma-Aldrich). Hexanal analysis were performed only to (C) control group, BHT group, $0.1 \%$ GYM and $0.1 \%$ RYM samples.

\section{Sensory analysis}

Hamburgers produced with BHT, 0.1\% GYM and $0.1 \%$ RYM were fried until the internal center temperature reached $75^{\circ} \mathrm{C}$ and submitted to sensory evaluation. Forty untrained assessors evaluated the samples in relation to appearance and flavor using a nine-point hedonic scale, varying from "dislike extremely" to "like extremely", according to Stone and Sidel (1993).

\section{Statistical analysis}

Data are expressed as means and standard derivation of three replicates. Significant differences among means were determined by ANOVA and Tukey post-hoc at 5\% level using SPSS software (version 10).

\section{RESULTS AND DISCUSSION}

\section{General composition of hamburger and fatty acid profile}

Hamburgers' proximate composition was similar to that described in the Brazilian and American Food Tables (TACO, 2006), including cholesterol content (Table 1). The main fatty acids in the samples were C18:1, C16:0, C18:0 and C18:2. Saturated fatty acid (SFA) and unsaturated fatty acids (UFA) levels at day 1 were similar for all the hamburgers (approximately 40 and 60\%, respectively) (Table 1). After 90 days of storage, there was no significant change in the fatty acid profile of hamburgers ( $p>0.05)$; data not shown, which could be explained by the presence of the antioxidant, the use of good manufacture practices to prepare the hamburger and the low temperature of storage. These results were similar obtained by Baggio and Bragagnolo (2006) for hamburger. 
Table 1 - General composition of hamburger with different antioxidants *

\begin{tabular}{lcccc} 
& Roasted yerba maté extract & Green yerba mate extract & BHT & Control \\
\hline Moisture $(\%)$ & $65.23^{\mathrm{b}} \pm 0.54$ & $63.86^{\mathrm{a}, \mathrm{b}} \pm 0.52$ & $64.64^{\mathrm{b}} \pm 0.49$ & $62.95^{\mathrm{a}} \pm 0.80$ \\
Protein (\%) & $16.76^{\mathrm{a}} \pm 0.65$ & $18.66^{\mathrm{a}} \pm 0.50$ & $16.97^{\mathrm{a}} \pm 0.62$ & $17.59^{\mathrm{a}} \pm 0.35$ \\
Fat $(\%)$ & $10.88^{\mathrm{a}} \pm 1.03$ & $11.72^{\mathrm{a}} \pm 0.92$ & $10.87^{\mathrm{a}} \pm 0.80$ & $12.08^{\mathrm{a}} \pm 0.63$ \\
Ash $(\%)$ & $2.89^{\mathrm{a}} \pm 0.09$ & $2.96^{\mathrm{a}} \pm 0.07$ & $2.88^{\mathrm{a}} \pm 0.03$ & $3.06^{\mathrm{a}} \pm 0.13$ \\
Cholesterol $^{\mathrm{c}}$ & $5.13^{\mathrm{a}} \pm 1.50$ & $5.28^{\mathrm{a}} \pm 0.30$ & $6.76^{\mathrm{a}} \pm 0.15$ & $5.22^{\mathrm{a}} \pm 0.04$ \\
Fatty acids $^{\mathrm{d}}$ & & & & \\
C14:0 & & & & \\
C16:0 & $1.41^{\mathrm{a}} \pm 0.03$ & $1.46^{\mathrm{a}} \pm 0.01$ & $1.44^{\mathrm{a}} \pm 0.06$ & $1.51^{\mathrm{a}} \pm 0.03$ \\
C18:0 & $24.99^{\mathrm{a}} \pm 0.07$ & $25.37^{\mathrm{b}} \pm 0.05$ & $25.41^{\mathrm{b}} \pm 0.06$ & $25.64^{\mathrm{a}} \pm 0.00$ \\
SFA & $13.99^{\mathrm{a}} \pm 0.53$ & $13.52^{\mathrm{a}} \pm 0.26$ & $13.48^{\mathrm{a}} \pm 0.061$ & $13.34^{\mathrm{a}} \pm 0.37$ \\
C16:1 & $40.38^{\mathrm{a}} \pm 0.62$ & $40.36^{\mathrm{a}} \pm 0.32$ & $40.32^{\mathrm{a}} \pm 0.61$ & $40.49^{\mathrm{a}} \pm 0.40$ \\
C17:1 & $2.04^{\mathrm{a}} \pm 0.05$ & $2.11^{\mathrm{a}} \pm 0.00$ & $2.08^{\mathrm{a}} \pm 0.02$ & $2.09^{\mathrm{a}} \pm 0.00$ \\
C18:1 & $0.36^{\mathrm{a}} \pm 0.00$ & $0.34^{\mathrm{a}} \pm 0.00$ & $0.34^{\mathrm{a}} \pm 0.00$ & $0.36^{\mathrm{b}} \pm 0.00$ \\
C18:2 & $44.72^{\mathrm{a}} \pm 0.49$ & $44.72^{\mathrm{a}} \pm 0.17$ & $44.60^{\mathrm{a}} \pm 0.03$ & $44.24^{\mathrm{a}} \pm 0.15$ \\
C18:3 & $11.03^{\mathrm{a}} \pm 0.03$ & $11.12^{\mathrm{a}} \pm 0.14$ & $11.32^{\mathrm{a}} \pm 0.56$ & $11.46^{\mathrm{a}} \pm 0.23$ \\
C20:2 & $0.81^{\mathrm{a}} \pm 0.02$ & $0.80^{\mathrm{a}} \pm 0.01$ & $0.78^{\mathrm{a}} \pm 0.01$ & $0.80^{\mathrm{a}} \pm 0.00$ \\
UFA & $0.32^{\mathrm{a}} \pm 0.00$ & $0.31^{\mathrm{a}} \pm 0.01$ & $0.32^{\mathrm{a}} \pm 0.02$ & $0.32^{\mathrm{a}} \pm 0.01$ \\
\hline V & $59.62^{\mathrm{a}} \pm 0.62$ & $59.64^{\mathrm{a}} \pm 0.32$ & $59.68^{\mathrm{a}} \pm 0.61$ & $59.51^{\mathrm{a}} \pm 0.40$ \\
\hline
\end{tabular}

Values are mean \pm standard deviation of three replicates $*$ data refer to day 1

${ }^{a-b}$ Values with different superscripts within a line are significantly different $(p<0.05)$.

${ }^{c} \mathrm{mg} \mathrm{g}^{-1}$ fat

${ }^{\mathrm{d}}$ Fatty acids profile (\%)

SFA= saturated fatty acid

UFA $=$ unsaturated fatty acid

\section{Lipid peroxidation: TBARs, cholesterol oxides and hexanal}

Yerba maté extracts (both green and roasted) at $0.01 \%$ were unable to stop the lipid peroxidation (Fig. $1 \mathrm{~A}$ ). Although $0.01 \%$ is the upper limit allowed under most countries' legislation for synthetic antioxidant addition to meat products, natural antioxidant extracts are only effective when added at 0.02 to $1.0 \%$ of the total product weight, a proportion which usually exceeds the regulation limits (Sasse et al., 2009; Ahn et al, 2007; Estévez et al., 2007; Ahn et al., 2002).

Adding $0.1 \%$ of yerba maté extracts to hamburgers resulted in effective protection against the peroxidation, as measured by TBARs assay, performing equivalent to BHT (Fig. $1 \mathrm{~B}$ ). The levels of MDA ranged from $0.5-3.0 \mathrm{mg}$ $\mathrm{MDA} / \mathrm{Kg}$ in the control hamburger; from $0.5-0.7$ mg MDA / Kg in the BHT hamburger; from $0.6-$ $0.8 \mathrm{mg} \mathrm{MDA} / \mathrm{Kg}$ in the GYM hamburger and 0.5 - $0.7 \mathrm{mg}$ MDA $/ \mathrm{Kg}$ in the RYM hamburger. Previous studies have shown that the addition of green yerba maté extracts to sausages and chicken products were also effective (Racanicci et al., 2008; Campos et al., 2007).

Cholesterol is susceptible to oxidation, leading to harmful products, which are implicated in patological processes, such as atherogenesis. Trace amounts of $25-\mathrm{OH}$ cholesterol were detected in all hamburguer groups, which did not change during 90 days' storage. Other cholesterol oxides (7-Keto, $7 \alpha-\mathrm{OH}$ and $7 \beta-\mathrm{OH})$ were not detected (detection limit $=1.59 \mathrm{E}-0.7 \mathrm{~g})$ (Fig. $2 \mathrm{~A}$ and B). Vicente and Torres (2007) detected no cholesterol oxide in meat hamburgers even after deep frying.

Hexanal is a carbonyl compound used to predict the lipid peroxidation and product sensory adequacy since its presence even at low levels is associated with rancid odor (Sasse et al., 2009; Campo et al., 2006; Gray et al., 1996). Hexanal (detection limit $=0.58 \mathrm{ug} / \mathrm{g}$ sample) was not detected at day 1 or during frozen storage. It is known that the rate of generation of volatile compound decreases at temperatures as low as the temperature employed in the present study $\left(-20^{\circ} \mathrm{C}\right)$ (Teets and Were, 2008; Ahn et al., 2007; Park et al., 2007; Brunton et al., 2000).

Lipid peroxidation had only a minor impact on the product quality during 90-day frozen storage. This was likely due to the raw material quality and the observance of good manufacturing practices. Among the oxidation parameters studied, only TBARs varied during the storage period (90 days). 

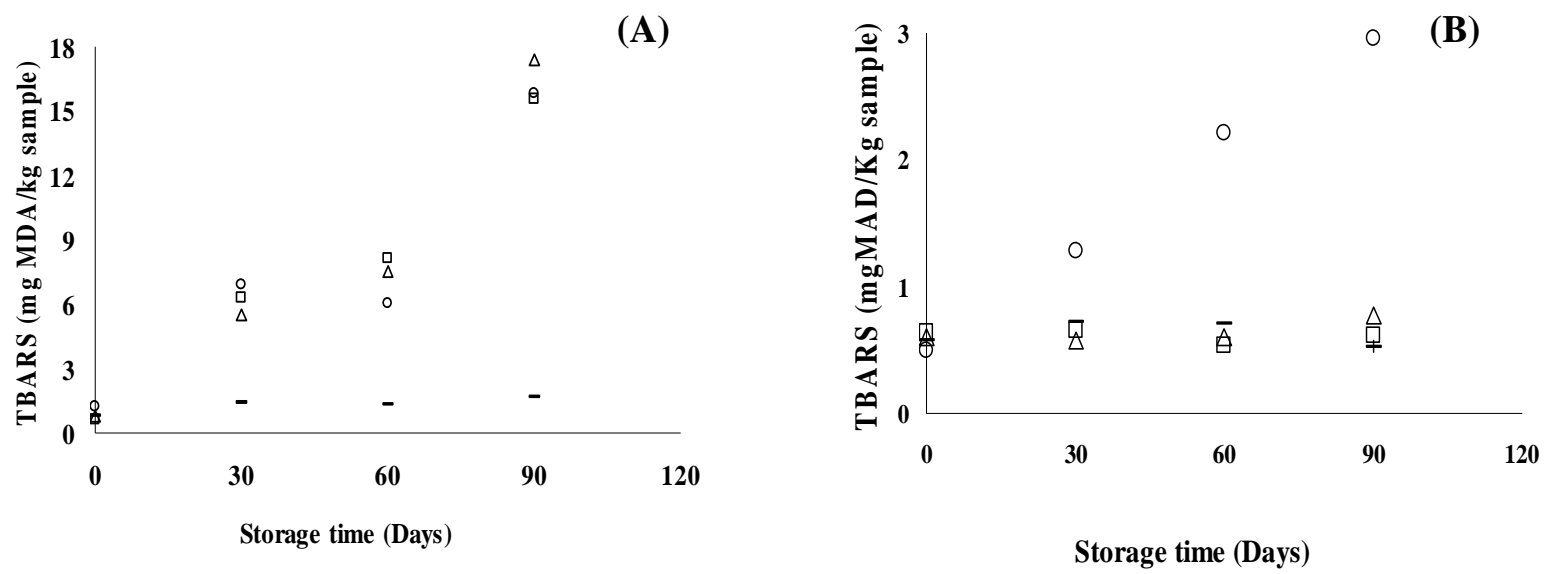

Figure 1 - Evolution of TBARs during refrigerated storage of hamburgers containing (A) $0.01 \%$ or (B) $0.1 \%$ of yerba maté extracts

$\square=$ Hamburger with maté tea extract

$\Delta=$ Hamburger with green yerba maté extract

- = Hamburger with BHT (butil-hidroxi-tolueno)

$\mathrm{O}=$ Hamburger without antioxidant or extracts
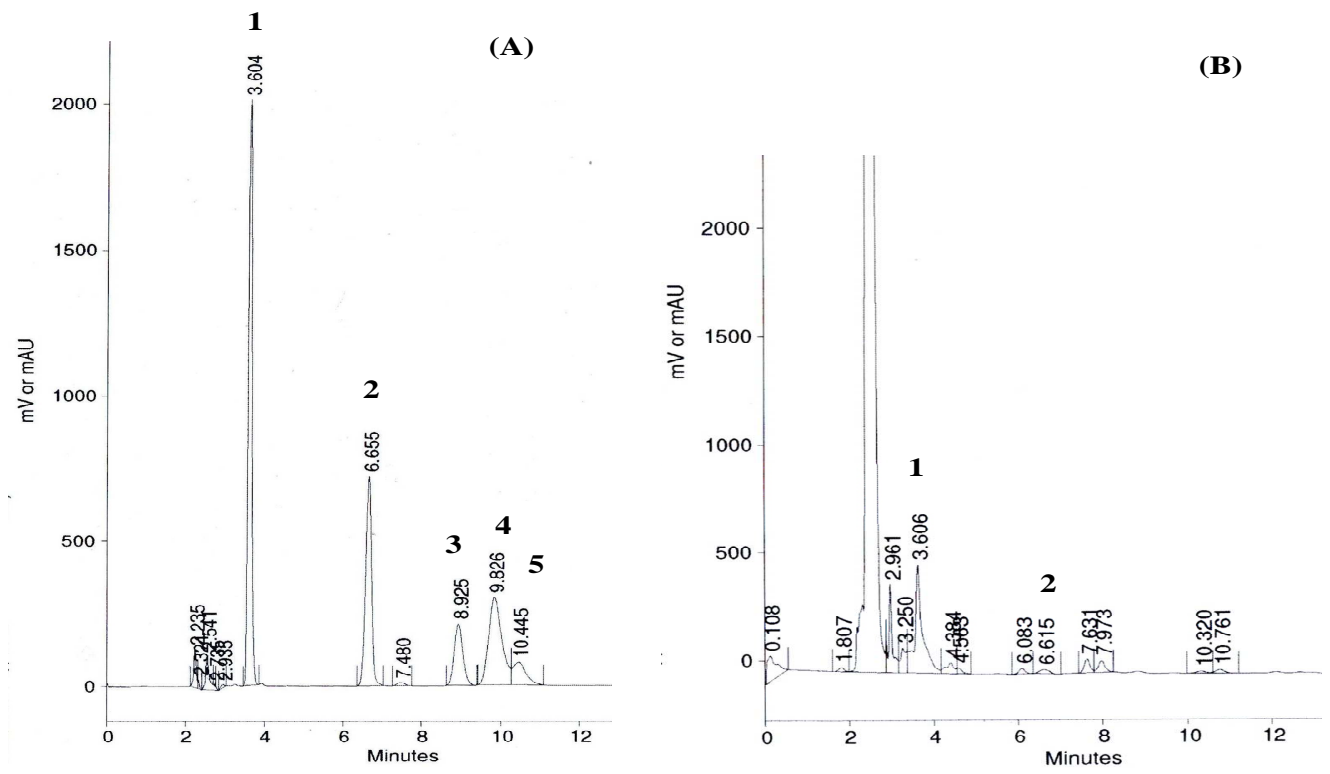

Figure 2 - (A) Cholesterol and cholesterol oxides standards (chromatogram at $206 \mathrm{~nm}$ ) and (B) Cholesterol and cholesterol oxides in hamburger without antioxidant (control group) after 90 days storage (chromatogram at 206nm). 1-Cholesterol; 2- 25-OH; 3- 7-Keto; 4- $7 \alpha-\mathrm{OH} ; \quad 5-7 \beta-\mathrm{OH}$.

\section{Sensory analysis}

The global acceptability as well as flavor and appearance acceptability of hamburgers made with $0.1 \%$ of yerba mate (green or roasted) extract and burgers made with $0.1 \%$ BHT were evaluated. All hamburgers, independent of the antioxidant type, showed good acceptability (Table 2). Adding yerba maté ethanolic extracts (green or roasted) to 
hamburgers did not affect the degree of acceptance of this meat product. Hamburgers with either green yerba maté or roasted yerba maté extracts were rated with the same average grade (7.0) for the tested attributes (flavor and appearance).This pattern was similar for the hamburgers made with BHT. It was noteworthy that adding yerba mate extracts did not affect hamburger approval by the panelists, since more than $77.5 \%$ of the volunteers graded the hamburgers with a score of 7 points or more (on a 9-point scale). These results indicated that adding yerba mate extracts did not impair hamburger color or flavor.

Table 2 - Mean scores for sensory acceptance for hamburgers with different antioxidants at $0.1 \%(\mathrm{w} / \mathrm{w})$

\begin{tabular}{cccc}
\hline & Flavor & Appearance & Global \\
\hline Roasted yerba maté & $7.3 \pm 1.8^{\mathrm{a}}$ & $7.4 \pm 1.5^{\mathrm{a}}$ & $7.2 \pm 1.8^{\mathrm{a}}$ \\
Green yerba maté & $7.1 \pm 1.7^{\mathrm{a}}$ & $7.2 \pm 1.5^{\mathrm{a}}$ & $6.9 \pm 1.6^{\mathrm{a}}$ \\
BHT & $7.3 \pm 1.2^{\mathrm{a}}$ & $6.9 \pm 1.7^{\mathrm{a}}$ & $7.3 \pm 1.2^{\mathrm{a}}$ \\
\hline
\end{tabular}

Values with different superscripts within a column are significantly different $(\mathrm{p}<0.05) ; \mathrm{n}=40$ panelists

\section{CONCLUSION}

Yerba maté ethanolic extracts were effective against lipid peroxidation in beef hamburger when added at $0.1 \%$. Furthermore, adding these natural antioxidants to hamburger did not result in sensory loss. These extracts could represent an alternative to synthetic antioxidants in meat products if added at concentrations above those established by the regulations (100 ppm). Therefore, if natural antioxidants are to fully replace synthetic antioxidants, legal limits must be revised.

\section{REFERENCES}

Ahn, J., Grün I. U., and Mustapha A. (2007). Effects of plants extracts on microbial growth, color change and lipid oxidation in cooked beef. Food Microbiol., 24, 7-14.

Ahn, J., Grün, I. U., and Fernando, L. N. (2002). Antioxidant properties of natural plant extracts containing polyphenolic compounds in cooked ground beef. J Food Sci., 67(4), 1364-1369.American oil chemists society (AOCS) (2002). Official Methods and Recommended Practices of the American Oil Chemists' Society ( $5^{\text {th }}$ ed.). Washington.

Association of official analytical chemists (AOAC) (1995). Official methods of analysis, $16^{\text {th }}$ ed., Arlington.

Baggio, S. R. and Bragagnolo, N. (2006). Cholesterol oxide, cholesterol, total lipid and fatty acid contents in processed meat products during storage. $L W T, 39$, 513-520.

Bastos, D. H. M., Fornari, A. C., Queiroz, Y. S., and Torres, E. A. F. S. (2006). Bioactive compounds content of chimarrão infusions related to the moisture of yerba maté (Ilex paraguariensis) leaves. Braz. Arch. Biol. Technol., 49(3), 399-404.

Bastos, D. H. M., Fornari, A. C., Queiroz, Y. S., Manólio, R. A., and Torres, E. A. F. S. (2005). The chlorogenic acid and caffeine content of yerba maté (Ilex paraguariensis) beverages. Acta Farm. Bonaerense, 24(1), 91-95.

Bastos, D.H.M., Oliveira, D. M., Matsumoto, R. L., Carvalho, P. O., and Ribeiro, M. L. (2007). Yerba maté: pharmacological properties, research and biotechnology (invited review). Med. Aromat. Plant Sci. Biotechnol., 1, 37-46.

Bastos,D.H.M.; Massumi T. K.; Bombo A. J.(2009) Alcoholic e.g. raw Paraguay tea extract based nutrient natural antioxidant consists of a liposoluble highly active substitute for synthetic antioxidants. Patent Number: BR200604916-A.

Brunton, N. P., Cronin, D. A., Monahan, F. J., and Durcan R. (2000). A comparison of solid-phase microextraction (SPME) fibre for measurement of hexanal and pentanal in cooked turkey. Food Chem., 68, 339-345.

Campo, M. M., Nute, G. R., Hughes, S. I., Enser, M., Wood, J. D., and Richardson, R. I. (2006). Flavor perception of oxidation in beef. Meat Sci., 72, 303 311.

Campos, R. M. L., Hierro, E., Ordónez, J. A., Bertol, T. M., Terra, N. N., and de la Hoz, 1. (2007). Fatty acid and volatile compounds from salami manufactured with yerba mate (Ilex parguariensis) extract and pork back fat and meat from pigs fed on diets with partial replacement of maize with rice bran. Food Chem., 103, $1159-1167$.

Csallany, A.S., Ayaz, K.L. (1976). Quantitative determination of organic solvent soluble lipofrescin pigments in tissues. Lipids, 11:412-417.

Dwivedi, S., Vasavada, M. N., and Cornforth, D. (2006). Evaluation of antioxidant effects and sensory attributes of chinese 5-spice ingredients in cooked ground beef. J Food Sci., 71(1), 12 - 17. 
Estévez, M., Ramírez, R., Ventanas, S., and Cava, R. (2007). Sage and rosemary essential oils versus BHT for the inhibition of lipid oxidative reactions in liver pâté. Food Sci. Technol., 40, 58 - 65.

Folch, J., Lees, M., and Stanley, G. H. S. (1957). A simple method for the isolation and purification of total lipids from animal tissues. J Biol. Chem., 226, $497-509$.

Gray, J. I., and Pearson, A. M. (1987). In. Flavor of meat and meat products ed. F. Shahidi. Blackie academic and professional, Glasgow, 250.

Gray, J. I., Gomaa, E. A., and Buckley, D. J. (1996). Oxidative quality and shelf life of meats. Meat Sci., 43, $111-123$.

Hernández-Hernández, E., Ponce-Alquicira, E., Jaramillo-Flores, M. E., and Legarreta G. I. (2009). Antioxidant effect of rosemary (Rosmarinus officinalis L.) and oregano (Origanum vulgare L.) extracts on TBARS and colours of model raw pork batters. Meat Sci., 81, 410 - 417.

Mazzafera, P. (1997). Maté drinking: caffeine and phenolic acid intake. Food Chem., 60(1), 67 - 71.

Metcalfe, L.D., Schmitz, A.A., and Pelka, J.R. (1966). Rapid Preparation of Fatty Acid Esters from Lipids for Gas Chromatographic Analysis. Anal. Chem. 38, p. 514-515.

Nawar, W.W. (1996). Lipids. In: Fennema O R, editor. Food chemistry (3rd ed.). New York: Marcel Dekker, nc 225-319.

Park, S. Y. et al. (2007). Evaluation of lipid oxidation and oxidative products as affected by pork meat CUT, packaging method, and storage time during frozen storage $\left(-10^{\circ} \mathrm{C}\right)$. J Food Sci., 72(2), $114-119$.

Pérez-Mateos, M., Lanier, T. C., and Boyd, 1. C. (2006). Effects of rosemary and green tea extracts on frozen surimi gels fortified with omega-3 fatty acids. J Sci. Food Agr., 86, 558 - 567.

Pokorný J. (2007). Are natural antioxidants better - and safer - than synthetic antioxidants? Eur. J Lipid Sci. Tech., 109, 629-642.

Racanicci, A. M. C., Danielsen, B., and Skibsted, L. H. (2008). Mate (Ilex paraguariensis) as a source of water extractable antioxidant for use in chicken meat. Eur. Food Res. Tech.,27(1), 255 - 260.
Sasse, A., Colindres, P., and Brewer, M. S. (2009). Effect of natural and synthetic antioxidants on the oxidative stability of cooked, frozen pork patties. $J$ Food Sci., 74(1), 30-35.

Schilderman P., ten Vaarwerk, F. J., Lutgerink, J. T., van der Wurff, A., ten Hoor, F., and Kleinjans, J. C. S. (1995). Induction of oxidative DNA damage and early lesions in rat gastro-intestinal epithelium in relation to prostaglandin $\mathrm{H}$ synthase-mediated metabolism of butylated hydroxyanisole. Food Chem. Toxicol., 33, 99-109.

Singleton, V.L, Rossi, J. A. Jr. (1965). Colorimetry of total fenolics with phosphomolybdic-phosphotungstic acid reagents. Am. J Enol. Vitic., 16: 144-158.

Sorensen, G., AND Jorgensen, S. S. (1996). A critical examination of some experimental variables in the 2thiobarbituric acid (TBA) test for lipid oxidation in meat products. Z Lebensm. Unters. Forsch., 202, 205 -210 .

Stone, H., and Sidel, J. L. (1993). Sensory Evaluation Practices. $2^{\mathrm{a}}$ ed. San Diego: Academic Press.

TACO - Tabela Brasileira de Composição de Alimentos (2006). In-Núcleo de Estudos e Pesquisas em Alimentação - UNICAMP, $2^{\text {nd }}$ ed., Campinas, $113 p$.

Teets, A. S., and Were, L. M. (2008). Inhibition of oxidation in refrigerated and frozen salted raw minced chicken breasts with electron beam irradiated almond skin powder. Meat Sci., 80, 1326 - 1332.

Vicente, S .J. V., and Torres, E. A. F. S. (2007). Formation of four cholesterol oxidation products and loss of free lipids, cholesterol and water in beef hamburgers as a function of thermal processing. Food Control, 18(1), $63-68$.

Vyncke, M. (1975). Evaluation of the direct thiobarbituric acid extraction method for determining oxidative rancidity in mackerel (Scomber scombrus L.). Fette Seifen Anstrichimittel, 77(6), 239-240.

Received: June 15, 2010; Revised: October 07, 2010; Accepted: March 14, 2011. 